\title{
PENGARUH PENAMBAHAN LAURIL ALKOHOL TERHADAP SIFAT-SIFAT UJI TARIK KOMPOSIT KARET ALAM TERISI SILIKA
}

\section{EFFECT OF LAURYL ALCOHOL ADDITION ON TENSILE PROPERTIES IN SILICA FILLED NATURAL RUBBER COMPOSITES}

\author{
Rieska Wulandari Sianturi, Indra Surya* \\ Departemen Teknik Kimia, Fakultas Teknik, Universitas Sumatera Utara, \\ Jalan Almamater, Medan, 20155, Indonesia \\ *Email: indradanas@yahoo.mail.com
}

\begin{abstract}
Abstrak
Dengan menggunakan vulkanisasi semi-effisien, penelitian mengenai pengaruh penambahan lauril alkohol sebagai bahan aditif baru terhadap persentase pembengkakan dan sifat-sifat uji tarik komposit karet alam terisi silika telah dilakukan. Pengisi silika yang digunakan adalah sebanyak 30 bagian per seratus bagian karet alam (bsk). Lauril alkohol merupakan fatty alcohol yang berasal dari minyak inti kelapa sawit dan dimasukkan ke dalam komposit karet alam terisi silika. Kadar lauril alkohol yang digunakan adalah 1,0 bsk; 2,0 bsk; 3,0 bsk dan 4,0 bsk. Lauril alkohol berfungsi sebagai bahan pemlastis internal. Lauril alkohol menurunkan modulus-modulus tarik $100 \%$ dan $300 \%$ dan meningkatkan pemanjangan saat putus bagi komposit karet alam terisi silika tersebut. Lauril alkohol juga meningkatkan kerapatan sambung silang dan kekuatan tarik dengan penambahan hingga 3,0 bsk Penambahan lauril alkohol sebanyak 3,0 bsk merupakan kadar optimum bagi komposit karet alam terisi silika.
\end{abstract}

Kata kunci: karet alam, lauril alkohol, silika, persentase pembengkakan, sifat-sifat uji tarik

\begin{abstract}
By using a semi-efficient vulcanisation system; the effects of lauryl alcohol (LA) as a new rubber additive on tensile properties of silica-filled natural rubber (NR) composites were investigated. The NR composites were filled by silica filler with a fixed loading, $30.0 \mathrm{phr}$ (part per hundred rubber). The LA is a fatty alcohol based on palm kernel oil and incorporated into the silica-filled NR composites. The LA loadings were $1.0 \mathrm{phr}, 2.0 \mathrm{phr}, 3.0 \mathrm{phr}$ and $4.0 \mathrm{phr}$. It was found that LA functioned as an internal plasticiser. As an internal plasticiser, LA decreased the tensile modulus and increased elongations at break of silica-filled NR composites. It was also found that LA increased the crosslink density and tensile strength up to $3.0 \mathrm{phr}$ of LA loading. The $3.0 \mathrm{phr}$ of LA was the optimum loading.
\end{abstract}

Keywords: natural rubber, lauryl alcohol, silica, swelling percentage, tensile properties

\section{Pendahuluan}

Karet alam termasuk ke dalam elastomer yang bersifat plastis dan lemah [17]. Untuk mendapatkan karet yang elastis, keras dan kuat dilakukan melalui reaksi vulkanisasi. Vulkanisasi adalah suatu proses sambung silang sulfur dengan molekul karet sehingga membentuk rangkaian tiga dimensi. Komposit karet tidak lagi bersifat lengket (tacky), tidak melarut tetapi hanya mengembang didalam pelarut organik tertentu [18].

Campuran karet alam dengan bahan kimia (bahan aditif) yang belum divulkanisasi disebut komposit karet. Bahan aditif yang digunakan diantaranya adalah bahan pemvulkanisasi, bahan pengisi, anti oksidan, bahan pemlastis (plasticizer) dan bahan kimia lainnya [2]. Penambahan bahan pengisi yang bersifat menguatkan (reinforcing filler), bertujuan untuk meningkatkan modulus, kekuatan tarik, ketahanan kikis dari komposit karet. Bahan pengisi penguat yang umum digunakan dalam pembuatan barang jadi karet adalah karbon hitam (carbon black) dan silika [11].

Banyak faktor yang menentukan derajat penguatan (degree of reinforcement) yang dihasilkan oleh suatu pengisi terhadap karet [15]. Salah satu yang terpenting adalah interaksi permukaan antara pengisi dengan molekul karet. Interaksi tersebut sangat dipengaruhi oleh interaksi kimia pada permukaan, baik dari pengisi maupun molekul karet sendiri. Pada permukaan pengisi silika terdapat sejumlah gugus silanol yang menjadikan silika menjadi bahan yang polar dan bersifat hidrofilik. Gugus silanol ini relatif tidak serasi dengan karet alam yang non polar, interaksi antara keduanya lemah dan partikel silika cenderung berinteraksi sesamanya dan membentuk gumpalan (agglomerate). Aglomerasi menyebabkan dispersi silika yang kurang merata sehingga pengaruh penguatan silika menjadi rendah [15]. 
Untuk meningkatkan dispersi pengisi digunakan bahan pemlastis. Pemlastis berfungsi untuk melunakkan karet, memudahkan pencampuran bahan kimia terutama bahan pengisi ke dalam komposit karet, mempersingkat waktu, menurunkan suhu pengkompositan, menghambat terjadinya waktu pra vulkanisasi, serta dapat memudahkan pembentukan barang jadi karet [9]. Pada penelitian ini digunakan pemlastis yang berasal dari turunan minyak inti kelapa sawit berupa lauril alkohol.

Penelitian ini mengkaji pengaruh lauril alkohol terhadap sifat-sifat uji tarik komposit karet alam terisi silika. Pengaruh kadar lauril alkohol terhadap persentase pembengkakan juga dikaji.

\section{Teori}

Karet Alam adalah polimer hidrokarbon yang berasal dari emulsi kesusuan pohon karet, Hevea brasiliensis (Euphorbiaceae) yang diperoleh dengan cara melukai kulit pohon karet sehingga menghasilkan lateks karet alam [14]. Vulkanisasi merupakan proses yang bertujuan untuk menurunkan plastisitas dan meningkatkan elastisitas, kekuatan dan kemantapan karet dengan membentuk ikatan silang pada rantai poliisoprena [12].

Produk karet alam umumnya memiliki kekuatan mekanik yang rendah. Oleh sebab itu, dalam pengolahannya perlu ditambahkan penguat seperti pengisi [4]. Pengisi biasanya digunakan untuk meningkatkan sifat-sifat mekanikal dari vulkanisat karet alam seperti kekuatan tarik, ketahanan terhadap pengikisan dan pengoyakan atau untuk memurahkan ongkos suatu produk karet. Berdasarkan efek penguatan terhadap sifat-sifat karet, maka pengisi dapat dikelompokkan menjadi 3 yaitu penguat (reinforcing), semi penguat dan bukan penguat (non reinforcing) [19].

Karbon hitam (carbon black) dan silika adalah pengisi penguat yang paling banyak digunakan untuk karet [2]. Silika merupakan senyawa amorphous yang mengandung silikon dan oksigen yang tersusun dalam struktur tetrahedral. Penggunaan silika banyak dalam industri-industri, dikarenakan sifat dan morfologinya yang unik, diantaranya: luas permukaan dan volume porinya yang besar. Penggunaan silika memberi keuntungan yaitu dapat menghasilkan produk yang transparan atau menghasilkan kombinasi warna dengan penguatan yang tinggi [1].

Pemlastis merupakan bahan aditif yang luas digunakan dalam industri karet dan plastik. Penggunaan bahan pemlastis dalam pembuatan barang jadi karet adalah untuk meningkatkan fleksibilitas polimer dan pendispersian bahan pengisi di dalam matrik. Fungsi utama dari pemlastis dalam kompon karet adalah untuk menurunkan pemanasan akibat gesekan bahanbahan selama pemprosesan. Pemlastis pada kompon karet dapat menurunkan modulus dan kekerasan serta meningkatkan pemanjangan saat putus.

Palm kernel oil (PKO) dapat menghasilkan berbagai produk turunan, diantaranya berupa fatty alcohol. Fatty alcohol turunan dari PKO memiliki banyak kelebihan, selain mudah didapat, murah, penggunaannya juga menghasilkan produk yang tidak beracun dan mudah terbiodegradasi [7]. Contoh senyawa fatty acohol adalah lauril alkohol $\left(\mathrm{C}_{12} \mathrm{H}_{26} \mathrm{O}\right)$, myristyl alcohol $\left(\mathrm{C}_{14} \mathrm{H}_{30} \mathrm{O}\right)$ dan lain-lain. Lauril alkohol, $\mathrm{CH}_{3}\left(\mathrm{CH}_{2}\right)_{10} \mathrm{CH}_{2} \mathrm{OH}$ memiliki struktur molekul yang unik, sebagiannya bersifat non-polar, sementara sebagian lainnya bersifat polar. Lauril alkohol berwujud cair dan bersifat oily liquid.

\section{Metodologi Penelitian \\ Bahan-bahan}

Sistem vulkanisasi sulfur terakselerasi semi-effisien digunakan untuk meneliti pengaruh lauril alkohol terhadap sifat-sifat uji tarik komposit karet alam terisi silika.

Tabel 1 menunjukkan bahan-bahan yang digunakan serta fungsi dan pemasoknya. Tabel 2 merupakan formulasi yang digunakan untuk penelitian.

\section{Peralatan-peralatan}

Peralatan yang digunakan meliputi timbangan analitik untuk mengukur massa sampel, two roll mill untuk mencampur bahanbahan, Rheometer untuk mengetahui karakteristik pematangan komposit, Tensometer untuk menguji sifat-sifat uji tarik dan Fourier Transform Infra Red untuk karakterisasi lauril alkohol.

\section{Pembuatan Kompon Karet Alam}

Karet alam, lauril alkohol, silika dan bahanbahan lainnya dicampur sampai keadaan homogen pada suhu konstan $\left( \pm 65-75^{\circ} \mathrm{C}\right)$ selama \pm 25 menit untuk satu siklus pencampuran di dalam two roll mill. Sampel senyawa karet yang berupa lembaran disimpan dengan kondisi \pm 21 $25^{\circ} \mathrm{C}$ selama \pm 24 jam di dalam freezer tertutup sebelum dilakukan pengujian sifat-sifat uji tarik. Pengujian Sifat-Sifat Uji Tarik

Sampel-sampel berbentuk dumble dipotong dari lembaran-lembaran vulkanisat karet dengan ketebalan $2 \mathrm{~mm}$ dengan pisau pemotong. Panjang dan lebar sampel 31-35 mm dan 6,2-6,4 $\mathrm{mm}$. Sampel ini diuji sifat uji tariknya. Prosedur 
pengujian sifat-sifat uji tarik dilakukan dengan melakukan standarisasi ASTM D 412-92 Test method A yaitu dengan menggunakan Tensometer Monsanto (Model T10) yang beroperasi dengan kecepatan $50 \mathrm{~cm} / \mathrm{min}$. Sifat- sifat uji tarik dilakukan dengan melakukan pembacaan kekuatan tarik dan persentase pemanjangan pada saat putus yang terekam dalam display dari tensometer pada setiap akhir pengujian.

Tabel 1. Bahan-bahan yang digunakan beserta fungsinya

\begin{tabular}{|l|l|l|}
\hline \multicolumn{1}{|c|}{ Nama bahan } & \multicolumn{1}{c|}{ Fungsi } & \multicolumn{1}{c|}{ Supplier } \\
\hline Karet alam & Bahan dasar & PTPN VII, Bandar Lampung \\
\hline ZnO & Accelerator activator & PT. Intancitra Logamindo, Medan \\
\hline Asam stearat & Accelerator coactivator & PT. Socimas, Medan \\
\hline MBTS* & Accelerator & Shandong Sunshine Chemical co.ltd, China \\
\hline IPPD** & Antioxidant & Jiangsu Sinorgchem co.ltd, China \\
\hline Sulfur & Crosslinker & Miwon Commercial co.ltd, Korea Selatan \\
\hline Lauril alkohol & Bahan additif baru & PT. Ecogreen, Batam \\
\hline Silika & Bahan pengisi & PT. JJ Degussa Hulls, Jakarta \\
\hline
\end{tabular}

*(Benzothiazolil disulfida)

**(N-Isopropil-N'phenil-p-phenilena diamina)

Tabel 2. Sistem vulkanisasi sulfur terakselerasi semi-efisien

\begin{tabular}{|l|l|l|l|l|l|}
\hline \multirow{2}{*}{\multicolumn{1}{|c|}{ Bahan }} & \multicolumn{5}{c|}{ Komposit (bsk) } \\
\cline { 2 - 6 } & \multicolumn{1}{|c|}{ A } & \multicolumn{1}{c|}{ B } & \multicolumn{1}{c|}{ C } & \multicolumn{1}{c|}{ D } & \multicolumn{1}{c|}{ E } \\
\hline Karet alam & 100,0 & 100,0 & 100,0 & 100,0 & 100,0 \\
\hline ZnO & 5,0 & 5,0 & 5,0 & 5,0 & 5,0 \\
\hline Asam stearat & 2,0 & 2,0 & 2,0 & 2,0 & 2,0 \\
\hline IPPD & 2,0 & 2,0 & 2,0 & 2,0 & 2,0 \\
\hline MBTS & 1,5 & 1,5 & 1,5 & 1,5 & 1,5 \\
\hline Sulfur & 1,5 & 1,5 & 1,5 & 1,5 & 1,5 \\
\hline Silika & 30,0 & 30,0 & 30,0 & 30,0 & 30,0 \\
\hline Lauril alkohol & 0,0 & 1,0 & 2,0 & 3,0 & 4,0 \\
\hline
\end{tabular}

\section{Pengujian Persentase Pembengkakan}

Pengujian persentase pembengkakan (swelling test) dilakukan dengan melarutkan komposit di dalam toluena berdasarkan ISO 1817. Potongan-potongan yang akan diuji (30mm x 5mm x $2 \mathrm{~mm}$ ) ditimbang menggunakan timbangan elektrik dan dimasukkan ke dalam toluen selama 72 jam hingga mencapai kesetimbangan, pada temperatur ruangan. Sampel dikeluarkan dari cairan, toluena yang masih tersisa di permukaan dihilangkan, lalu ditimbang. Sampel-sampel tersebut dikeringkan di dalam oven pada temperatur $80^{\circ} \mathrm{C}$ sampai berat konstan. Persentase pembengkakan karet alam di dalam toluena dinyatakan dengan Persamaan (1) berikut ini.

$\mathrm{S}(\%)=\frac{W_{2}-W_{1}}{W_{1}} \times 100 \%$

Dengan $\mathrm{W}_{1}$ adalah massa awal sampel (gram) dan $\mathrm{W}_{2}$ adalah massa sampel (gram) setelah perendaman.

\section{Hasil Dan Pembahasan}

\section{Uji FTIR Lauril Alkohol}

Adapun hasi FTIR dari lauril alkohol disajikan pada Gambar 1.

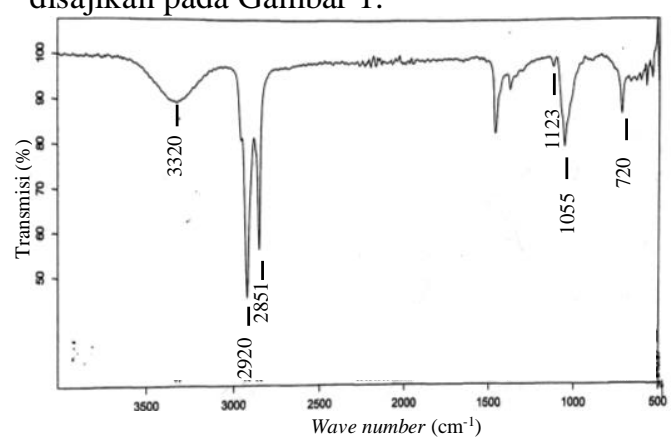

Gambar 1. FTIR lauril alcohol

Dari Gambar 1 dapat dilihat karakteristik FTIR yang menunjukkan beberapa serapan (peak) yang dapat mengindikasikan suatu gugus sebagai ciri khusus dari suatu senyawa. Pada sampel lauril alkohol terdapat beberapa puncak serapan yang muncul yaitu 3320, 2920, 2851, 1123, 1055 dan $720 \mathrm{~cm}^{-1}$. Puncak serapan pada bilangan gelombang $3320 \mathrm{~cm}^{-1}$ mengindikasikan keberadaan dari gugus $\mathrm{O}-\mathrm{H}$ (merujuk pada $\mathrm{O}-\mathrm{H}$ 
stretching). Puncak serapan pada bilangan gelombang $2920 \quad \mathrm{~cm}^{-1}$ mengindikasikan keberadaan gugus $\mathrm{C}-\mathrm{H}$ (merujuk pada $\mathrm{C}-\mathrm{H}$ stretching). Puncak serapan pada bilangan gelombang 2851, 1123, 1055 dan $720 \mathrm{~cm}^{-1}$ secara berurutan mengindikasikan keberadaan gugus $\mathrm{CH}_{3}$ (merujuk pada $\mathrm{CH}_{3}$ symetric), gugus $\mathrm{C}-\mathrm{C}$ (merujuk pada $\mathrm{C}-\mathrm{C}$ stretching), gugus $\mathrm{C}-\mathrm{O}$ dan gugus $\mathrm{CH}_{2}$ (merujuk pada $\mathrm{CH}_{2}$ bending) [13]. Dari serapan bilangan gelombang tersebut dengan jelas menunjukkan adanya bilangan gelombang dari gugus-gugus fungsional molekul lauril alkohol dengan rumus molekul $\mathrm{CH}_{3}\left(\mathrm{CH}_{2}\right)_{10} \mathrm{CH}_{2} \mathrm{OH}$.

\section{Pengaruh Penambahan Lauril Alkohol Terhadap Persentase Pembengkakan Komposit Karet Alam Terisi Silika}

Hasil berikut memperlihatkan pengaruh penambahan lauril alkohol terhadap persentase pembengkakan komposit karet alam terisi silika dapat dilihat pada Gambar 2.

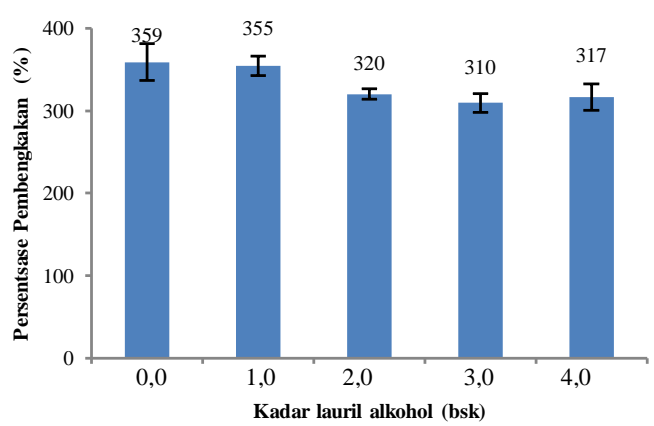

Gambar 2. Pengaruh penambahan lauril alkohol terhadap persentase pembengkakan komposit karet alam terisi silika

Dari Gambar 2 menunjukkan persentase pembengkakan menurun dengan penambahan lauril alkohol sebanyak 1,0 bsk. Hal ini disebabkan fungsi dari lauril alkohol sebagai bahan pemlastis yang membantu dispersi silika di dalam fasa karet sehingga memperkecil free volume komposit karet dan mempersulit mobilisasi zat pelarut. Penambahan yang lebih lanjut menyebabkan semakin berkurang persentase pembengkakan hingga 3,0 bsk. Hal ini menunjukkan derajat sambung silang fisik yang terbentuk semakin meningkat.

Setelah kadar 3,0 bsk persentase pembengkakan meningkat pada penambahan lauril alkohol lebih lanjut. Hal ini disebabkan oleh kerapatan sambung silang pada komposit karet alam yang menurun. Penambahan lauril alkohol yang berlebih akan menjebak silika dibagian dalam lapisannya dan membuat pengisi silika sulit diakses oleh karet alam sehingga derajat sambung silang fisik yang terbentuk akan menjadi rendah [16].

Pengaruh Penambahan Lauril Alkohol Terhadap Modulus Tarik Komposit Karet Alam Terisi Silika

Hasil berikut memperlihatkan pengaruh penambahan lauril alkohol terhadap modulus tarik komposit karet alam terisi silika dapat dilihat pada Gambar 3.

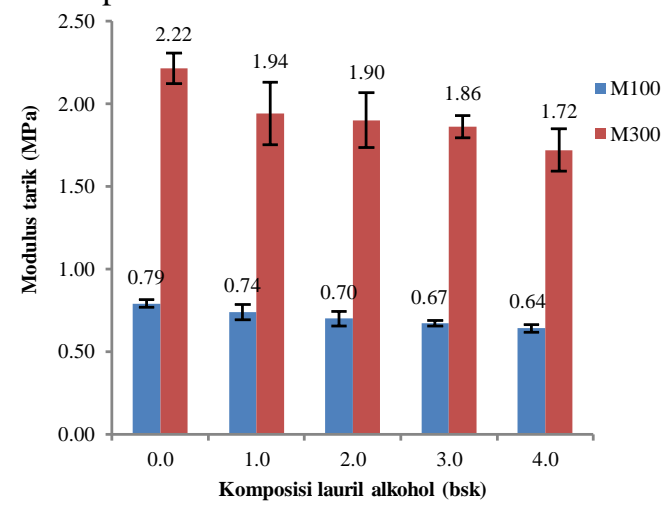

Gambar 3. Pengaruh Kadar Lauril Alkohol Terhadap Modulus Tarik Komposit Karet Alam Terisi Silika

Dari Gambar 3 terlihat bahwa penambahan lauril alkohol sebanyak 1,0 bsk menurunkan modulus tarik 100\% (M100) dan modulus tarik $300 \%$ (M300) pada komposit karet alam terisi silika. M100 dan M300 merupakan bagian dari sifat mekanik yang berhubungan langsung dengan tenaga yang dibutuhkan (usaha) untuk meregangkan [6]. Modulus tarik menggambarkan kekakuan/kekerasan (stiffness) [16]. Modulus yang tinggi mengindikasikan kekerasan yang lebih tinggi, sementara modulus yang rendah, mengindikasikan komposit yang lebih lembut.

Penambahan lauril alkohol sebanyak 1,0 bsk menurunkan kekerasan komposit sehingga komposit tersebut menjadi bersifat lebih lembut. Peningkatan kadar lauril alkohol sebesar 2,0 s/d 4,0 bsk, semakin melembutkan komposit tersebut. Hal ini disebabkan oleh lauril alkohol yang berfungsi sebagai pemlastis. Penambahan bahan pemlastis ke dalam komposit karet menurunkan viskositas komposit tersebut. Penurunan viskositas komposit menghasilkan komposit yang lebih lembut. Penambahan kadar lauril alkohol yang lebih banyak menyebabkan penurunan viskositas yang lebih lanjut.

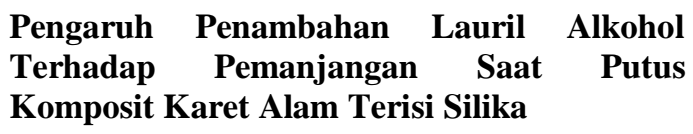


Hasil berikut memperlihatkan pengaruh penambahan lauril alkohol terhadap pemanjangan saat putus komposit karet alam terisi silika ditunjukkan pada Gambar 4.

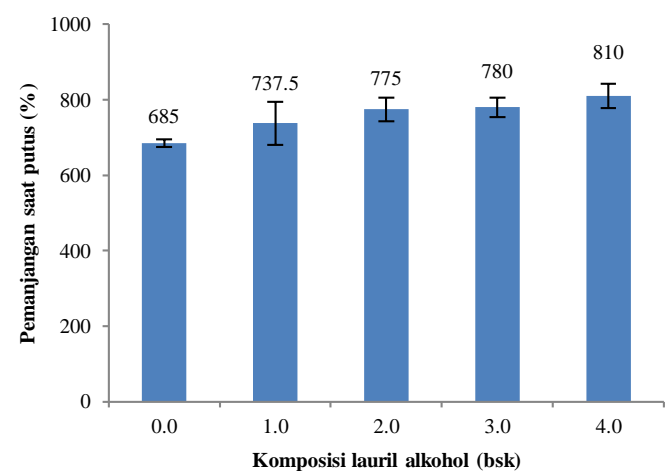

Gambar 4. Pengaruh Kadar Lauril Alkohol Terhadap Pemanjangan Saat Putus Komposit Karet Alam Terisi Silika

Dari Gambar 4 terlihat bahwa pemanjangan saat putus (\%) dari komposit karet alam terisi silika meningkat dengan penambahan lauril alkohol 1,0 bsk. Pemanjangan saat putus adalah pertambahan panjang yang terjadi dengan menarik sampel sampai putus [6]. Penambahan lauril alkohol ke dalam komposit karet alam terisi silika dapat meningkatkan ekstensibilitas dari komposit karet alam tersebut. Hal ini disebabkan oleh lauril alkohol yang bertindak sebagai pemlastis dalam komposit komposit karet alam terisi silika. Pemlastis adalah material pengkomposit yang digunakan tidak hanya untuk meningkatkan pemrosesan komposit karet tetapi juga memodifikasi sifat fisik dan bersumber dari minyak alam/lemak [19].

Lauril alkohol bersifat minyak (oily) dan berasal dari turunan minyak inti kelapa sawit sehingga meningkatnya kadar lauril alkohol mempunyai pengaruh yang sama sebagaimana meningkatnya jumlah bahan pemlastis yang akan meningkatkan kemampuan deformasi dengan meningkatnya kemampuan pemanjangan komposit karet alam terisi silika. Penambahan pemlastis dalam komposit karet menurunkan viskositasnya sehingga komposit karet lebih lunak. Makin besar pemlastis dalam komposit karet maka perpanjangan putus akan semakin tinggi. Hal tersebut disebabkan karena tiap unit volume karet yang diberi pemlastis mengandung rantai jaringan lebih panjang. Rata-rata rantai ini lebih panjang daripada dalam jaringan yang dibentuk tanpa adanya pemlastis. Akibatnya kekerasan turun dan elastisitas meningkat [3]. Penambahan lauril alkohol yang lebih lanjut menyebabkan peningkatan perpanjangan saat putus dari komposit karet.

\section{Pengaruh Penambahan Lauril Alkohol Terhadap Kekuatan Tarik Komposit Karet Alam Terisi Silika}

Hasil berikut memperlihatkan pengaruh penambahan lauril alkohol terhadap kekuatan tarik komposit karet alam terisi silika dapat dilihat pada Gambar 5

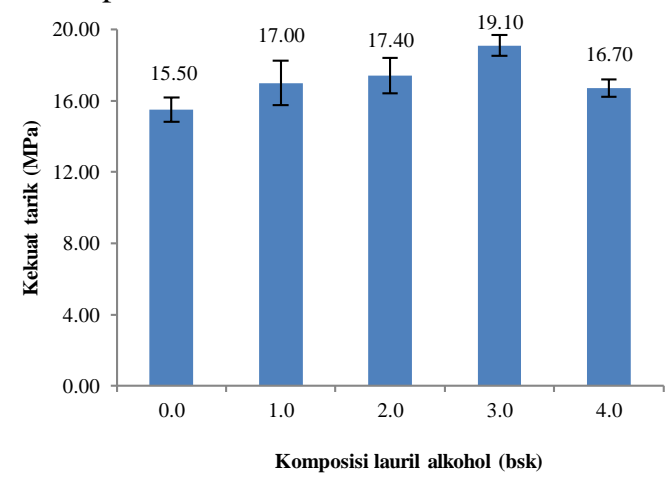

Gambar 5. Pengaruh Kadar Lauril Alkohol Terhadap Kekuatan Tarik Komposit Karet Alam Terisi Silika

Dari Gambar 5 terlihat bahwa kekuatan tarik komposit karet alam terisi silika meningkat dengan penambahan lauril alkohol sebanyak 1,0 hingga 3,0 bsk. Kekuatan tarik komposit karet dipengaruhi oleh kerapatan sambung silang dan dispersi pengisi dari komposit tersebut [16]. Hal ini disebabkan oleh lauril alkohol yang yang berfungsi sebagai pemlastis. Penambahan pemlastis meningkatkan derajat dispersi pengisi, sehingga menaikkan kekuatan tarik dan mempengaruhi kekuatan secara positif [5]. Penambahan lauril alkohol lebih lanjut menyebabkan penurunan kekuatan tarik komposit karet. Hal ini disebabkan oleh dampak dari lauril alkohol yang berlebih. Kelebihan bahan pemlastis berdampak pada kerapatan sambung silang yang menurun.

Lauril alkohol yang berasal dari turunan alkana mempunyai ukuran molekul yang cenderung rendah sehingga mudah menempati ruang antar molekul dalam rantai karet alam yang menyebabkan berkurangnya kekuatan sekunder diantara molekul karet alam, sehingga pada saat molekul karet mengalami peregangan, rasio bahan pengisi tidak dapat mengimbangi atau menempati ruang yang mengalami pelunakan. Hal ini menyebabkan molekul karet alam mudah bergerak dan tidak dapat menahan tarikan $[10,8]$.

\section{Kesimpulan}

Dari hasil yang diperoleh dapat disimpulkan bahwa,

1. Lauril alkohol berfungsi sebagai bahan pemlastis internal bagi karet alam terisi silika, 
karena menurunkan modulus $100 \%$ dan modulus $300 \%$ serta meningkatkan pemanjangan saat putus

2. Lauril alkohol meningkatkan kerapatan sambung silang dan kekuatan tarik komposit karet alam terisi silika.

3. Lauril alkohol menghasilkan komposit karet alam terisi silika yang lebih lunak dengan kekuatan tarik yang baik

4. Kadar lauril alohol optimum untuk komposit karet alam terisi silika adalah 3,0 bsk.

\section{Daftar Pustaka}

[1] B. Robert dan P. Sarnacke, Rubber Composites,Unitied Soybean Board, http://unitedsoybean.org, 2011, Diakses pada 19 September 2017

[2] H. M. Alfatih dan P. P. Ilmu, Studi Karakteristik Sifat Mekanik Komposit Karet Dengan Variasi Komposisi Sulfur dan Carbon Black sebagai Bahan Dasar Ban Luar, Simposium Nasional Teknologi Terapan (SNTT)3 - Surakarta., 2015.

[3] Herminiwati, N. D. Wahini, dan L. S. B. Pudji, Pemanfaatan Minyak Kulit Biji Mete sebagai Plasticizer dalam Pembuatan Sol Sepatu, Majalah Kulit, Karet, dan Platik, Vol. 20, (2004).

[4] L. Marfuah, H. Nuim dan H. Hamidah, Pengaruh Aging pada Kekuatan Tarik (Tensile Strength) Film Lateks Karet Alam Berpengisi Nanokristalin Selulosa dan Penyerasi Alkanolamida, Jurnal Teknik Kimia USU, Vol. 5, No. 2, (2016).

[5] M. Rizky, Skripsi, Pengaruh Tahap Pencampuran Carbon Black terhadap Sifat Fisik Karet, Fakultas Teknologi Pertanian, Institusi Pertanian Bogor, 1999.

[6] Nasruddin, Pengembangan Karet Alam dengan Bahan Pengisi dan Bahan Pelunak Menjadi Tube Collar, Prosiding Seminar Nasional Kulit, Karet dan Plastik ke-6, 2017.

[7] N. Mohamad, E. Zarina dan Y. M. Ambar, Penghasilan Surfaktan Tak Berion Berasaskan Lauril Alkohol daripada Terbitan Minyak Kelapa Sawit, The Malaysian Journal of Analytical Sciences Vol. 12, No. 1, (2008).

[8] N. D. Wahini, Supraptiningsih dan S. Nursamsi, Pengaruh Pemlastis Nabati terhadap Sifat Elastomer Termoplastik Berbasis Campuran Karet Alam/Polipropilena, Majalah Kulit, Karet, dan Platik, Vol. 31, (2015).

[9] P. Santi dan C. Adi, Karakterisasi Minyak Jarak Terhidrogenasi sebagai Bahan
Pelunak Karet Alami, Jurnal Penelitian Karet, Vol. 32, No.1, (2014).

[10] R. Arief dan F. M. Irfan, Pengaruh Asam Stearat terhadap Karakteristik Pematangan Sifat Mekanik dan Swelling Komposit Karet Alam dengan Bahan Pengisi Organoclay, Indonesian Journal of Materials Science, Vol. 14, No. 2, (2013).

[11] R. Arief, S. Bambang dan F. M. Irfan, Pengaruh Organobentonit dan Asam Stearat terhadap Karakteristik Pematangan dan Sifat Mekanik Komposit Karet Alam, Jurnal Penelitian Karet, Vol. 32, No. 1, (2014).

[12] S. A. Riga, Skripsi, Studi Pengaruh Ukuran Partikel dan Jumlah phr Carbon Black sebagai Bahan Pengisi terhadap Sifat Mekanik Produk Karet Alam, Fakultas Matematika dan Ilmu Pengetahuan Alam, Program Studi Kimia, Universitas Indonesia, 2012.

[13] S. M. Robert, F. X. Webster, dan D. J. Kiemle, Spectrometric Identification of Organic Compound, Edisi 7, John Wiley and Sons, Inc, 2006.

[14] S. I. M. Syafitri, Skripsi, Pengaruh Penambahan Alkanolamida terhadap Karakteristik Pematangan dan Kekerasan Komposit Karet Alam Berpengisi Kaolin, Departemen Teknik Kimia, Fakultas Teknik, Universitas Sumatera Utara, 2013.

[15] S. Indra, M.S. thesis, Reinforcment of Natural Rubber and Epoxidized Natural Rubbers with Amine-Treated Silica, Universiti Sains Malaysia, Malaysia, 2002.

[16] S. Indra, H. Ismail, dan A. R. Azura, Alkanolamide as an Accelerator, FillerDispersant and a Plasticizer in Silica-Filled Natural Rubber Composites", Polymer Testing, Vol. 32, (2013).

[17] T. F. Erdiana dan H. Hamidah, Pengaruh Suhu Vulkanisasi dan Komposisi Bentonite Clay yang Dimodifikasi dengan Alkanolamida dari Bahan Baku RBDPKO pada Produk Lateks Karet Alam, Jurnal Teknik Kimia USU, Vol. 4, No. 4, (2015).

[18] T. L. Harry, H. S. Darwis dan S. Indra, Pengaruh Penambahan Alkanolamida Terhadap Karakteristik Pematangan dan Kekerasan Komposit Karet Alam Berpengisi Silika, Jurnal Teknik Kimia USU. Vol. 1, No. 2, (2012)

[19] W. Yudha, Skripsi, Pengaruh Penambahan Alkanolamida terhadap Sifat-Sifat Uji Tarik Komposit Karet Alam Berpengisi Kaolin, Departemen Teknik Kimia, Fakultas Teknik, Universitas Sumatera Utara, 2014. 